\title{
Sebacina aureomagnifica (Sebacinales, Basidiomycota): an unexpected discovery from the Brazilian Caatinga
}

\author{
Wartchow F ${ }^{1}$, Sá MCA ${ }^{2}$, Conceição LB ${ }^{3}$, Silva DRC ${ }^{4}$ and Marques MFO ${ }^{4}$
}

\begin{abstract}
${ }^{1}$ Universidade Federal da Paraíba, Departamento de Sistemática e Ecologia/CCEN, CEP:58051-900, João Pessoa, PB, Brazil

${ }^{2}$ Universidade Federal do Rio Grande do Norte, Departamento de Botânica e Zoologia, Pós-Graduação em Sistemática e Evolução, Campus Universitário, Lagoa Nova, CEP 59072-970, Natal, RN, Brazil

${ }^{3}$ Universidade Estadual de Feira de Santana, Departamento de Ciência Biológicas, Programa de Pós-Graduação em Botânica, Avenida Transnordestina, s/n, Novo Horizonte, 44036-900, Feira de Santana, Brazil

${ }^{4}$ Universidade do Estado da Bahia, Departamento de Educação, Campus VII, Rod. Lomanto Júnior, Br 407, Km 127, CEP: 48970-000, Senhor do Bonfim, BA, Brazil
\end{abstract}

Wartchow F, Sá MCA, Conceição LB, Silva DCR, Marques MFO 2017 - Sebacina aureomagnifica: an unexpected discovery in the Brazilian Caatinga. Studies in Fungi 2(1), 157161, Doi 10.5943/sif/2/1/17

This article is dedicated to friend and colleague Prof. Dr. Marcos Fábio Oliveira Marques, who suddenly passed away in August $2^{\text {nd }}, 2017$, at the age of 37 (in memoriam)

\begin{abstract}
Sebacina aureomagnifica, recently described from Atlantic Forest is recorded for the first time from the Brazilian Caatinga Biome of Bahia, Brazil. Full description, photographs of the basidiome, drawings of the microstructures and a discussion of $S$. aureomagnifica are provided.
\end{abstract}

Key words - Agaricomycetes - Neotropic - Sebacinaceae - taxonomy

\section{Introduction}

The genus Sebacina Tul. \& C. Tul. includes ectomycorrhizal heterobasidiomycetes that are characterized mostly by the exidioid basidia, i.e. longitudinally septate without clamp connections and presence of branched sterile hyphal elements known as dikaryophyses (Oberwinkler et al. 2014, Weiß et al. 2016). Recent check list about Brazilian jelly fungi by Alvarenga \& XavierSantos (2015) reported S. fuliginea (Rick) L.S. Olive from the state of Rio Grande do Sul and $S$. stratosa (Viégas) L.S. Olive from the state of São Paulo. Earlier work by Rick (1958) referred $S$. argillacea Rick, $S$. atra var. macrospora Rick, S. luteocinerea Rick, S. luteostraminea (Rick) Rick, S. rosea (Rick) Rick, S. sordidoalba (Rick) Rick and S. tenuissima Rick from Rio Grande do Sul. However, their identity should be confirmed by using modern species concept. Actually, only two publications refer to Sebacina in Brazil: an unidentified species from Paraná (de Meijer 2006) and the recently described S. aureomagnifica from Atlantic Forest of Northeast Brazil (Wartchow et al. 2015).

The northeastern Brazilian Caatinga is a semi-arid biome with more elevated temperature and high potential evapotranspiration, which aggravate the effect of low and irregular rainfall (Coutinho 2006: 20-21). Into this biome, the Serra da Fumaça, is a region with a forest called Seasonal Semideciduous Forest (Zacca \& Bravo 2012). Here we report for the first time the recently 
described S. aureomagnifica Wartchow, Sulzbacher \& Ovrebo from the biome Caatinga, in the Brazilian Caatinga Biome from the state of Bahia.

\section{Materials \& Methods}

Sebacina aureomagnifica basidiome was collected in 'Serra da Fumaça' (10³9' S, 40²2' W), Pindobaçu, Bahia state, Brazil, along a trail of 'Floresta Estacional Semidecidual', with some parts characterized by the sandy soil (Milesi et al. 2002). A floristic study in the region was performed only with the family Rubiaceae, referring 36 species belonging to 20 genera (Souza et al. 2013).

The description of the macroscopic features was based on fresh material. Kornerup \& Wanscher (1978) was followed for color codes and names. Description of the microscopic features was based on dried specimens. Dry specimens were rehydrated in water or $3 \% \mathrm{KOH}$ for spore dimensions, and then mounted in Congo red to observe the hymenium and pileipellis, and in mounted in water for pigment localization. Twenty-five spores were measured. Extreme measurements are indicated within parentheses. The following abbreviations were used for spore measurements (adapted from Tulloss et al. 1992): L (W) = average length (width) of the basidiospores measured; $\mathrm{Q}=$ spore quotient (length/width ratio); $\mathrm{Qm}=$ average spore quotient.

\section{Results}

Sebacina aureomagnifica Wartchow, Sulzbacher \& Ovrebo, Mycol. Prog. 14: 109. 2015. Figs 1-3

Basidiomes epigeous and erect, arising in a single pair from a single base, gelatinous when fresh, tough after dryng; merulioid-helvelloid. Each cluster to $40 \mathrm{~mm}$ wide, $60 \mathrm{~mm}$ high; pale yellow (3A3) then more slightly yellowish (5A3-5A4) mostly at base, then dull grayish orange (5B4) at very base; tips cupulate to tubulate tips, frequently anastomosing; both stipe and tips joined at base; hollow near base.

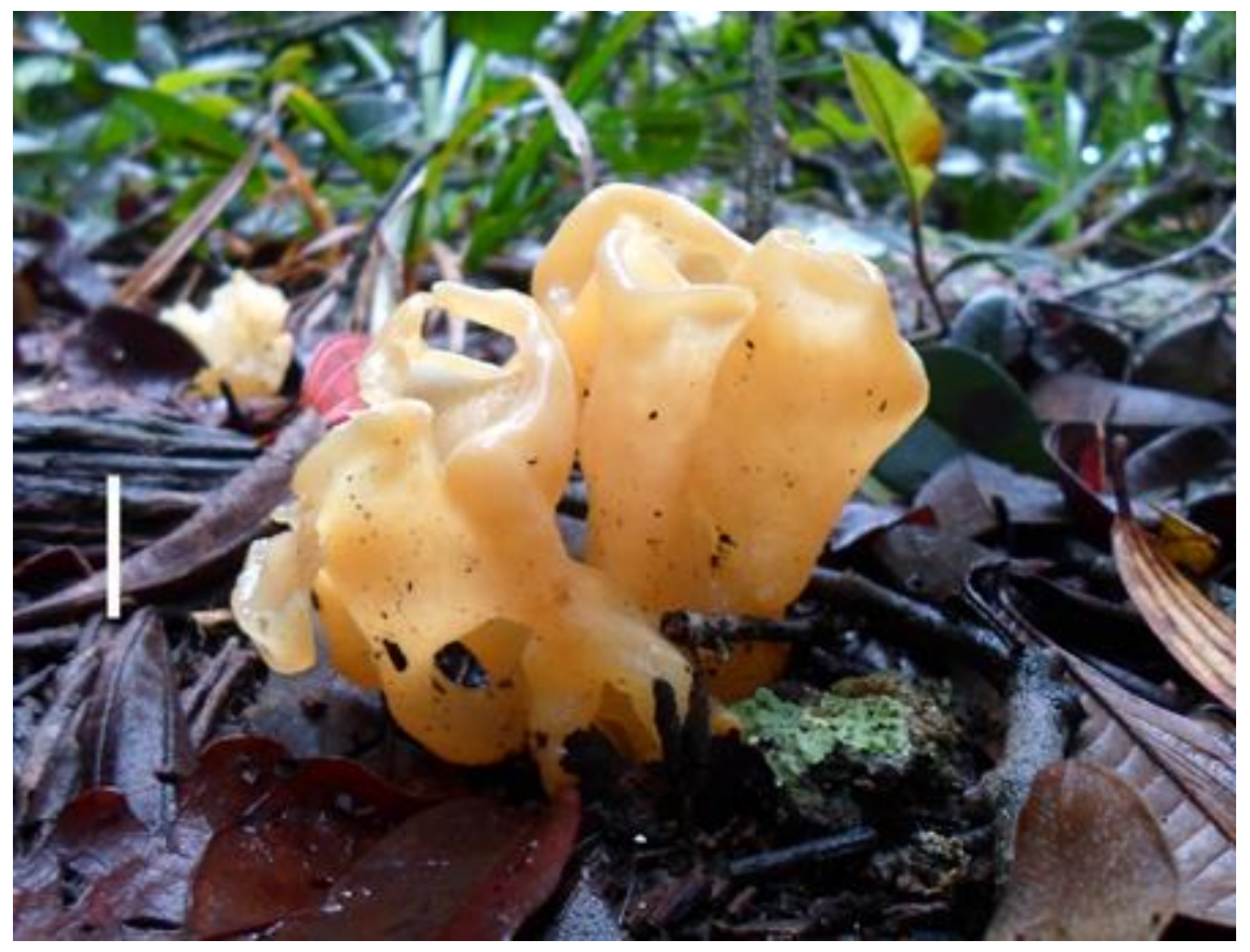

Fig. 1 - Sebacina aureomagnifica (JPB 63207). Basidiome in situ. Scale bar $=20 \mathrm{~mm}$. 


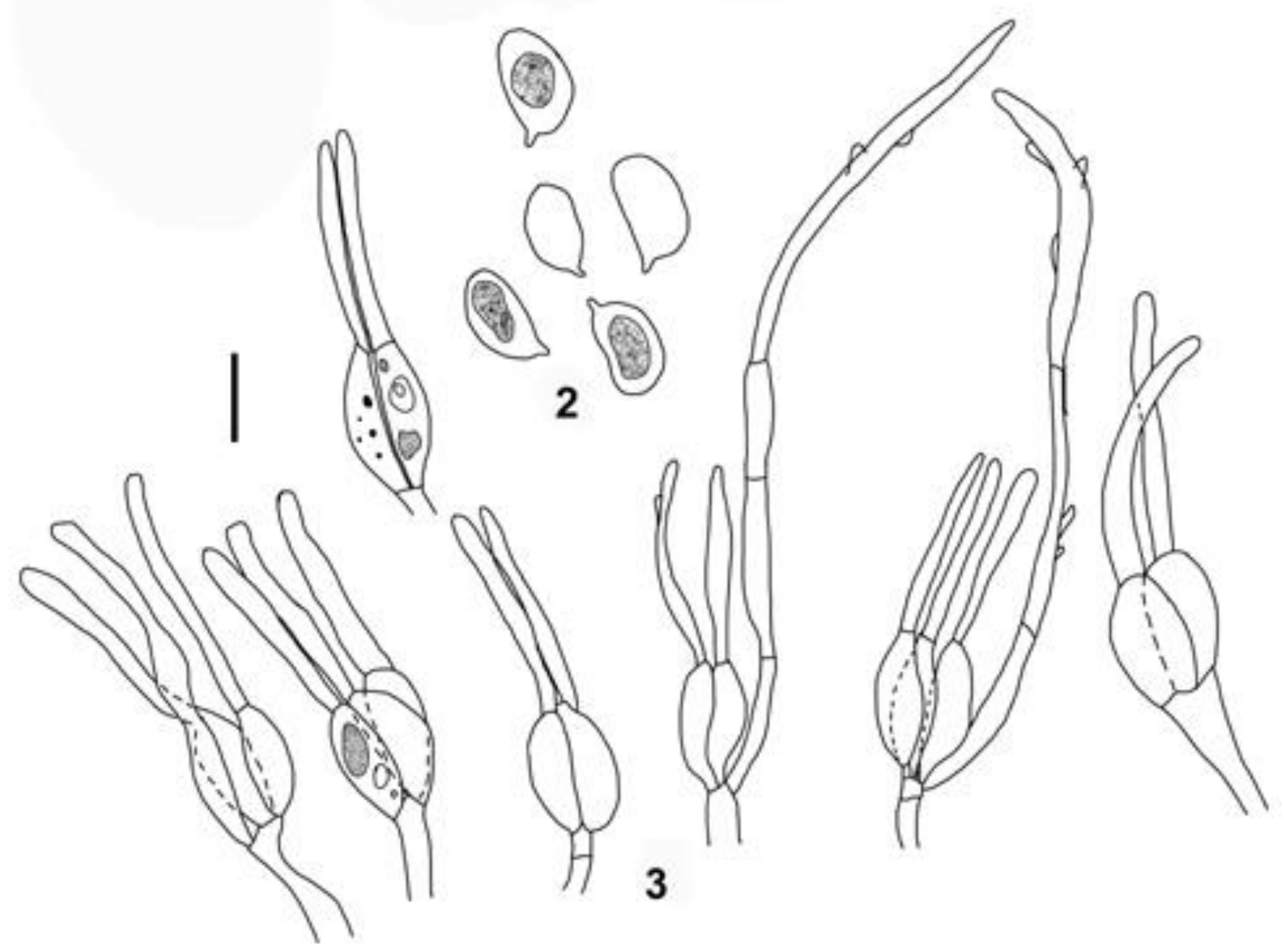

Figs. 2-3 - Sebacina aureomagnifica (JPB 63207). 2 Basidiospores. 3 Basidia and dikaryophyses. Scale bar $=10 \mu \mathrm{m}$.

Basidiospores 9.5-12 (-12.5) × (5.3-) 5.5-6.5 $\mu \mathrm{m}, \mathrm{L}=10.3 \mu \mathrm{m}, \mathrm{W}=6 \mu \mathrm{m}, \mathrm{Q}=1.58-1.89(-$ 1.92), $\mathrm{Qm}=1.71$; hyaline, inamyloid, ellipsoid to elongate, frequently adaxially flattened, smooth, thin walled, sometimes with two guttules. Basidia exidioid, 13.5-17.5 ×9-10.5 $\mu \mathrm{m}$ (whole width), mostly 4 celled, whole basidium subglobose or broadly ovoid in side view, short-stalked, each cell broadly clavate to clavate; sterigmata one for each cell, $15-25 \mu \mathrm{m}$ long and $2.5 \mu \mathrm{m}$ wide. Immature basidia 11-13 $\times 8-10 \mu \mathrm{m}$. Hymenium showing abundant sparingly ramified dikaryophyses, some knobbed and sometimes dichotomously ramified at their apex, ranging to $90 \mu \mathrm{m}$ long. Cystidia absent. Context monomitic; comprising by about $3.5 \mu \mathrm{m}$ wide hyphae, mostly thin-walled, immersed in a gelatinous matrix. Clamp connections absent from all septa observed.

Known distribution - Atlantic Forest from Paraíba and Rio Grande do Norte, and now in Caatinga from Bahia (Fig. 4).

Habitat - on sandy soil.

Material examined - Brazil, Bahia, Pindobaçu, Serra da Fumaça, 10³8'59"S and 40²2'25"W, 06 June 2015, L.B. Conceição, D.R.C. da Silva \& L.S. Santa Luzia FW 13/2015 (JPB 63207).

\section{Discussion}

The material analyzed here agrees in several aspects with the protologue by Wartchow et al. (2015), as for example, the erect yellow basidiomes, the basidiospores and the knobbed/diverticulate dikaryophyses that are key features of our mushroom. The only difference is the presence of slightly narrower basidiospores in Bahia collection, (5.3-) 5.5-6.5 $\mu \mathrm{m}$ and $\mathrm{Qm}=$ 1.71 instead of (5.3-) 5.5-7 $\mu \mathrm{m}$ and $\mathrm{Qm}=1.65$ in the original description. 
Although mostly having resupinate habit, i.e. flat on the substrate with the hymenium in the other side (Kirk et al. 2008), other species with erect basidiomes were already described in this genus (Oberwinkler et al. 2014). Sebacina candida (Schwein.) Oberw., Garnica \& K. Riess, S. ocreata (Berk.) Oberw., Garnica \& K. Riess and S. sparassoidea P. Roberts easily differ in forming coralloid basidiomes (Roberts 2003, Oberwinkler et al. 2014). Sebacina pallida (Schwein.) Oberw., Garnica \& K. Riess differs in having the spatulate to clavarioid basidiomes (Oberwinkler et al. 2014); and S. pileata P. Roberts produces concentrically zonate bracket-like grayish pilei, finely hirsute with hymenial surface on underside of the pileus showing pinkish-gray drying ochraceous to pale brick color (Roberts 2008).

Sebacina aureomagnifica was previously described from an area of Atlantic Forest in the states of Paraíba and Rio Grande do Norte, is now reported for the first time from the biome Caatinga in the state of Bahia, Brazil.

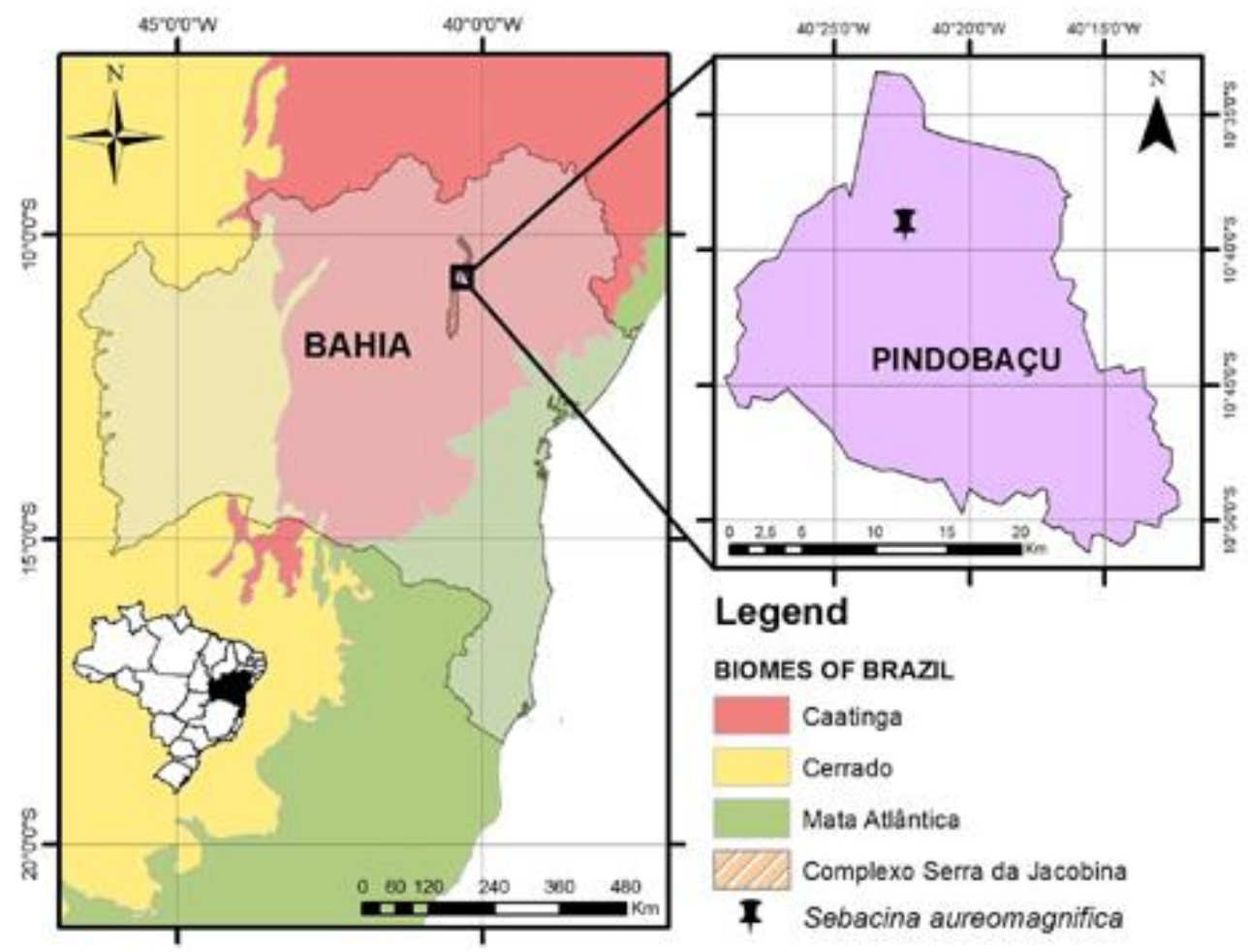

Fig. 4 - Maps showing the occurrence of the new collection of Sebacina aureomagnifica in Bahia.

\section{Acknowledgements}

The field trips were financed by $\mathrm{CNPq}$ (Programa de Pesquisa em Biodiversidade do Semiárido457476/2012-5). LBC is grateful to the Universidade do Estado da Bahia (UNEB), the Conselho Nacional de Desenvolvimento Científico e Tecnológico, the Fundação de Amparo à Pesquisa do Estado da Bahia (FAPESB) and Programa de Pós-Graduação em Botânica (PPGBot/ UEFS) for support. FW thanks to 'Conselho Nacional de Desenvolvimento Científico e Tecnológico' (CNPq) for the 'Produtividade em Pesquisa' (Proc. 307922/2014-6) Grant, and MCAS to 'Coordenação de Aperfeiçoamento de Pessoal de Nível Superior' (CAPES) for PhD scholarship.

\section{References}

Alvarenga RLM, Xavier-Santos S. 2015 - A checklist of Jelly Fungi. Mycotaxon 130, 925-926. Coutinho LM. 2006 - O conceito de bioma. Acta Botanica Brasilica 20, 13-23. 
Kirk PM, Canon PF, Minter DW, Stalpers JA. 2008 - Ainsworth \& Bisby's Dictionary of the Fungi. CAB International, Wallingford.

Kornerup A, Wanscher JH. 1978 - Methuen Handbook of Colour. $3^{\text {rd }}$ ed. Eyre Methuen, London.

de Meijer AAR. 2006 - Preliminary list of the macromycetes from the Brazilian state of Paraná. Boletim do Museu Botânico Municipal (Curitiba) 68:1-55.

Milesi JP, Ledru P, Marcoux E, Mougeot R. 2002 - The Jacobina Paleoproterozoic gold-baring conglomerates, Bahia, Brazil: a "hydrothermal shear-reservoir" model. Ore Geology Reviews 9, 95-136.

Oberwinkler F, Riess K, Bauer R, Garnica S. 2014 - Morphology and molecules: the Sebacinales, a case study. Mycological Progress 13, 445-470.

Rick J. 1958 - Basidiomycetes eubasidii in Rio Grande do Sul - Brasilia. I. Iheringia Serie Botânica 2, 1-56.

Roberts P. 2003 - Sebacina concrescens and S. sparassoidea: two conspicuous but neglected North American Sebacina species. Sydowia 55, 348-354.

Roberts P. 2008 - Heterobasidiomycetes from Belize. Kew Bulletin 63, 87-99.

Souza LA, Bautista HP, Jardim JG. 2013 - Diversidade florística de Rubiaceae na Serra da Fumaç - complexo de Serras da Jacobina, Bahia, Brasil. Biota Neotropica 13, 289-314.

Tulloss RE, Ovrebo CL, Halling RE. 1992 - Studies on Amanita (Amanitaceae) from Andean Colombia. Memoirs of the New York Botanical Garden 66, 1-46.

Wartchow F, Sulzbacher MA, Selosse M-A, Grebenc T. 2015 - Sebacina aureomagnifica, a new heterobasidiomycete from the Atlantic Forest of Northeast Brazil. Mycological Progress 14, 109.

Weiß M, Waller F, Zuccaro A, Selosse M-A. 2016 - Sebacinales - one thousand and one interactions with land plants. New Phytologist 211, 20-40.

Zacca T, Bravo F. 2012 - Borboletas (Lepidoptera: Papilionoidea e Hesperioidea) da porção norte da Chapada da Diamantina, Bahia, Brasil. Biota Neotropica 12, 1-10. 